\title{
Delta asymmetry: Concepts, characteristics, and depositional models
}

\author{
Li Weiguo ${ }^{1,2 *}$, Janok P. Bhattacharya ${ }^{2}$ and Wang Yingmin ${ }^{3}$
}

\author{
${ }^{1}$ BP America Inc., Houston, Texas77079, USA \\ ${ }^{2}$ Department of Earth and Atmospheric Sciences, University of Houston, Houston, Texas 77204-5007, USA \\ ${ }^{3}$ College of geosciences, China University of Petroleum, Beijing 102249, China
}

(c) China University of Petroleum (Beijing) and Springer-Verlag Berlin Heidelberg 2011

\begin{abstract}
Delta asymmetry forms in wave-influenced settings where there is strong net longshore drift. Asymmetric deltas typically have two sediment sources and are characterized by morphology and facies asymmetry between the downdrift and the updrift sides. The downdrift, sourced primarily by the feeding river, are commonly influenced by mixed river and wave processes. Deposits on this side are muddy and consist of barrier, bar, lagoon, bay-fill, and bayhead delta facies with variable bioturbation intensity. At or near the river mouth, heterolithic river-dominated successions are more typical. Deposits are overall unburrowed (BI 0-2), but with high burrowing spikes. Ichnogenera are characterized by horizontal, morphologically simple, and facies-crossing structures. The updrift, in contrast, is sourced by a second sediment source and typically consists of laterally continuous sandy beach and shoreface facies. Bioturbation is overall high (BI 3-6) and ichnogenera are healthy and robust, attributable to the Cruziana and Skolithos Ichnofacies. Depending on shoreline trajectory and depositional history, facies characteristics of asymmetric deltas preserved in the ancient record, however, can be different from those predicted by the models.

Degree of asymmetry is indicated by the asymmetry index (A), defined as the ratio between the rate of longshore transport at the river mouth and river water discharge. The indexes in symmetric waveinfluenced deltas is less than 200, whereas those in asymmetric and deflected deltas are larger than 200. Overall the larger the index, the higher the degree of asymmetry.

Delta asymmetry concepts and models challenge the traditional definition of deltas and the delta classification scheme. In a hydrocarbon exploration perspective, asymmetric deltas bear very different types of sands and, thus, reservoirs between the updrift and the downdrift. The updrift consists of wellsorted, mature, and laterally continuous homogeneous beach-shoreface reservoirs. The downdrift, in contrast, is muddier and consists of less continuous, less mature, heterolithic reservoirs.
\end{abstract}

Key words: Delta asymmetry, asymmetry index, longshore drift, wave-influenced deltas, ichnology

\section{Introduction}

The traditional definition of deltas and the processed-based deltaic classification scheme date back to the 1970s (Wright and Coleman, 1973; Coleman and Wright, 1975; Galloway, 1975) (Fig. 1). Deltas are classified as river-, wave-, and tidaldominated based on the relative importance of river, wave, and tidal process in shaping their morphology and internal facies. The early models suggest that wave-influenced deltas have arcuate and/or cuspate shapes with evenly distributed sands on both sides of the feeding rivers (Bhattacharya and Walker, 1992; Reading and Collinson, 1996). The

*Corresponding author. email: wgliuh@gmail. com or Weiguo.Li@bp.com

Received September 29, 2010 most important underlying premise of these models is that sediments accumulated on the two sides of river mouths are mainly from the feeding rivers. Without significant longshore drift and transport, the premise is correct and solid. Analysis of modern deltaic systems shows, however, that when there is strong net longshore drift the premise is questionable (Dominguez et al., 1987; Dominguez, 1996; Bhattacharya and Giosan, 2003). Computer modeling further demonstrates that, depending on wave energy, angle of wave approach, and rate of longshore transport, wave-influenced deltas can largely show asymmetric characteristics, with very different facies and morphology between the two sides of their feeding rivers (Komar, 1973). The first part of the paper, by involving several modern and ancient asymmetric deltas, focuses on the delta asymmetry concepts, characteristics, and depositional models; the second part elaborated the significances in studying these deltas. 


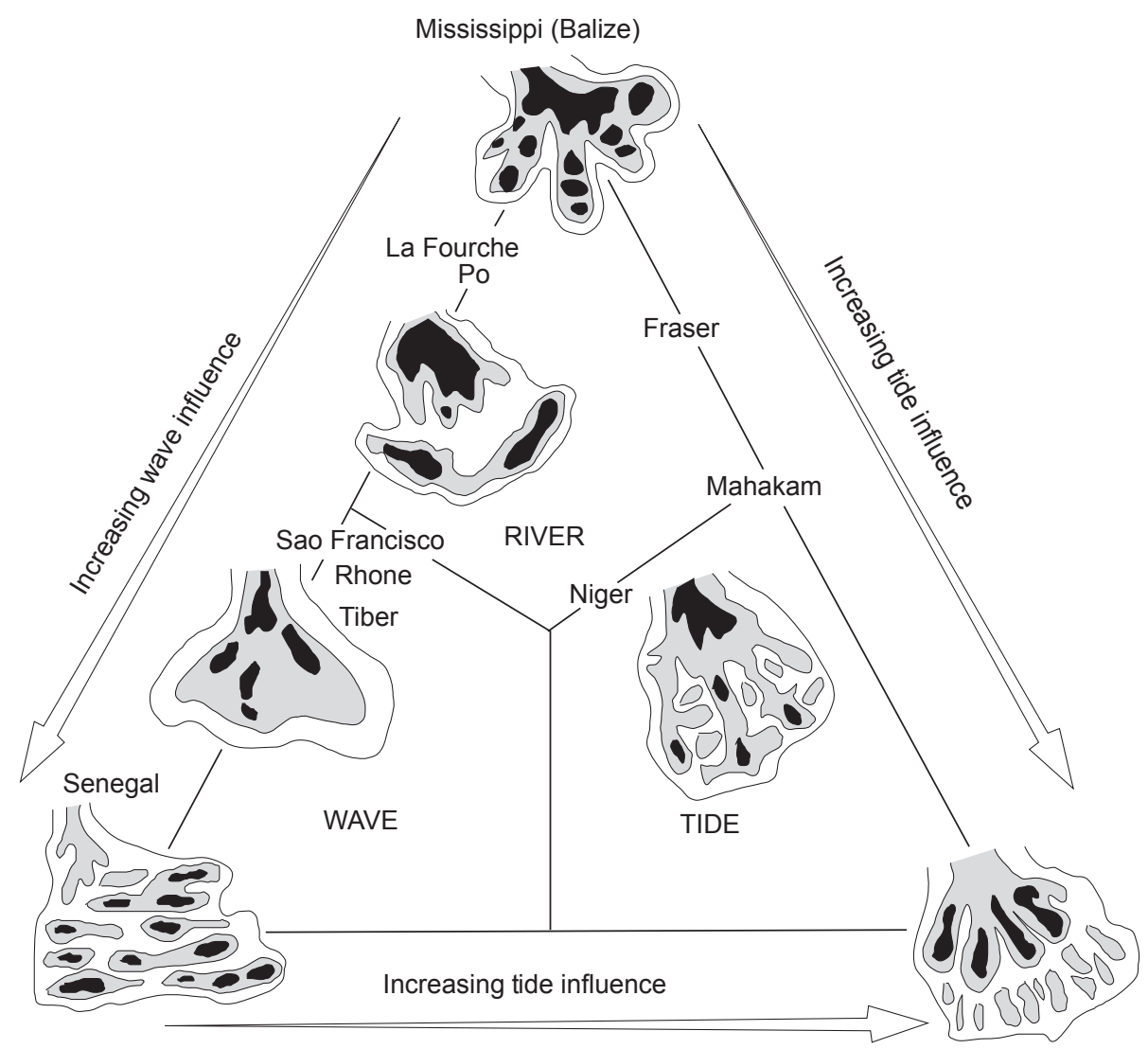

Fig. 1 Sand body geometries of the six basic delta types of Coleman and Wright (1975) plotted on the traditional process-based tripartite delta classification diagram of Galloway (1975). Deltas are commonly identified as wave-, river-, and tide-dominated based on the relative importance of these processes.

\section{Delta asymmetry: modern examples}

\subsection{The Danube delta and its asymmetric lobes}

The Danube Delta, located in Romania, currently has three active branches, each of which builds its own lobe (Fig. 2 ). The Chilia branch to the north is the largest, accounting for about $60 \%$ of water and sediment discharge from the Danube River system. Under the control of rapid sediment supply and a shallow and gentle shelf, the Chilia branch progrades rapidly into the basin, building a digitized lobe with well-developed terminal distributary channels and mouth bars (Fig. 2, lobe 3c). Deposits are overall river-dominated and heterolithic, with small marine bars formed under wave reworking fronting several terminal distributary channels. The Sulina branch further southward takes about $20 \%$ of the water and sediment discharge from the Danube River. Discharge in the branch is decreasing due to artificial interferences, and the Sulina lobe is currently under wave reworking and erosion (Fig. 2, lobe 2).

Similar to the Sulina branch, the southern most Sf. Gheorghe branch also accounts for $20 \%$ of the Danube discharge. However, under the control of basinal wave processes and, particularly, southward longshore currents, the branch is linked to a typical asymmetric lobe (Fig. 2, lobe 1b). On the updrift (the north side) it consists of laterally continuous shoreface and strandplain facies (the Sārāturile Formation), and the downdrift side, in contrast, is more heterolithic and composed of delta plain, lagoon, bay-fill, and linear bar deposits. Sediments on the downdrift side of the lobe show less maturity and have similar composition to those from the mouth bars. In contrast, those on the updrift side, more mature, are shed from the destructing Sulina lobe and are transported southward by longshore currents (Giosan, 1998). Sandy bars and ridges are typically separated by muddy facies, resulting in a uneven morphology with highs and lows. Lobes 1a and 2 shown in Fig. 2 also show asymmetry, bearing similar morphology and facies characteristics as described in the active Sf. Gheorghe lobe.

The linear bars and sand ridges on the downdrift sides of these asymmetric lobes are formed by reworking of distributary mouth bars by wave processes. Among them, the Sacalin bar is the youngest and it has been growing both downdrift and migrating shoreward during the past $100 \mathrm{yrs}$ under the effect of wave processes and longshore currents (Giosan, 1998). A semi-closed low-energy bay is developed behind the bar, into which small river-dominated bayhead deltas prograde (Fig. 2, b1, b2). 


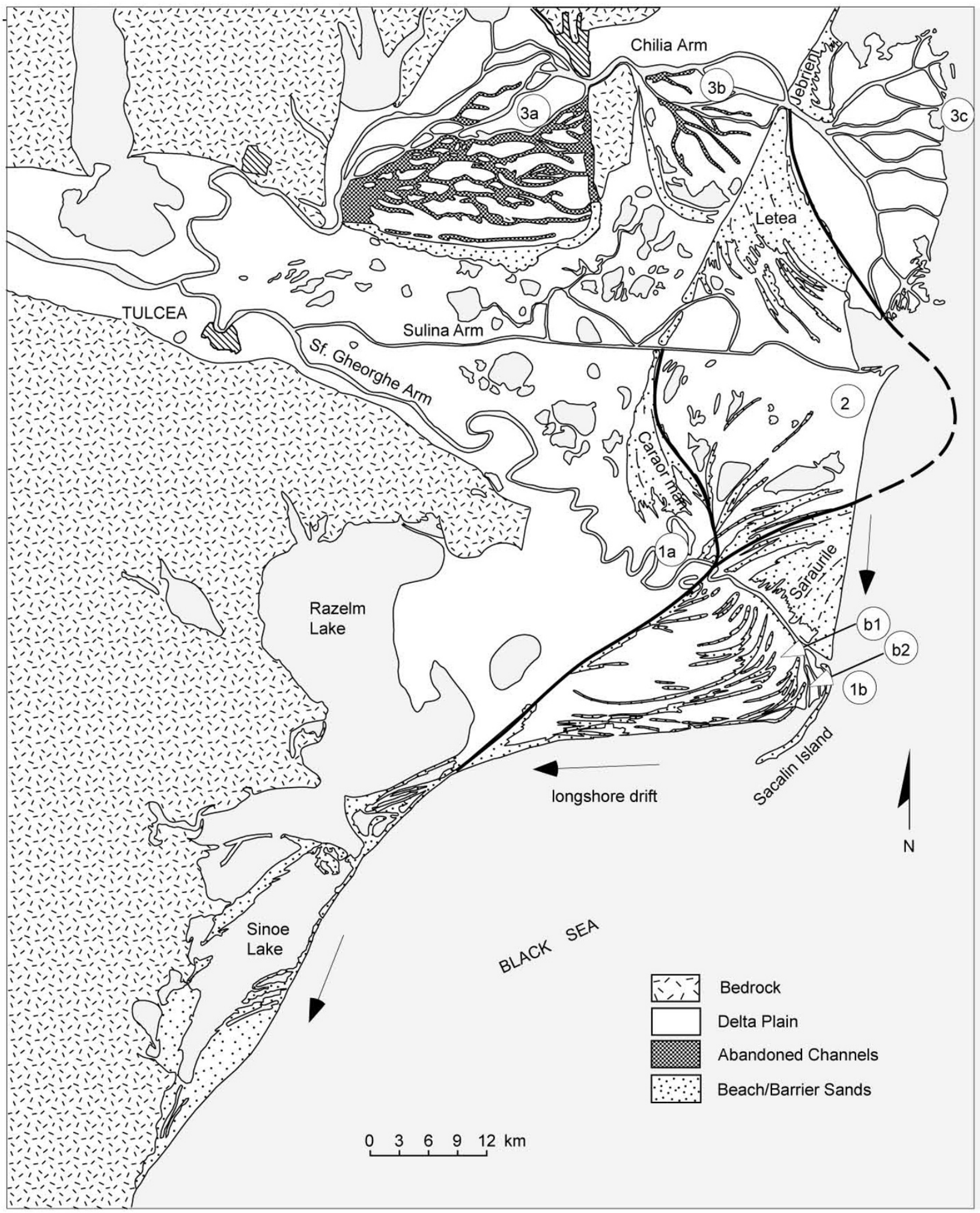

Fig. 2 Morphology and facies of the modern and relict lobes of the Danube delta. Longshore drift is southward as shown by the black arrows. Delta asymmetry occurs in a series of lobes, including both the relict (1a) and the active (1b) lobes built by the Sf. Gheorghe arm to the south and the destructing Sulina lobe (2) further north. The updrift sides of these asymmetric lobes consist of laterally continuous sandy beach ridge plains (i.e. the active Sārāturile Formation and the preserved Caraorman and Letea formations), whereas the downdrift sides consist mainly of muddy facies with sparse linear sandy ridges. The Sulina lobe (2) is under destruction, being reworked by basinal wave processes. The largely inactive Sulina lobe performs as a second source for the Sf. Gheorghe lobe in that sediments eroded are transported southward by longshore currents and are deposited on the updrift flank of the Sf. Gheorghe lobe, as the Sārāturile Formation. Two river-dominated, small bayhead deltas (b1, relict; b2, still active) occur behind the linear sandy bars and/or ridges on the downdrift of the Sf. Gheorghe lobe. Notice the internal facies complexity of the Danube delta. The northern, highest discharging Chilia arm deposited two successive lacustrine river-dominated deltas ( $3 \mathrm{a}$ and $3 \mathrm{~b})$ before reaching the coast and build another river-dominated lobe (3c), whereas the southern branches created wave-dominated lobes ( 1 and 2$)$. Data from Panin (1997) and Bhattacharya and Giosan (2003). 

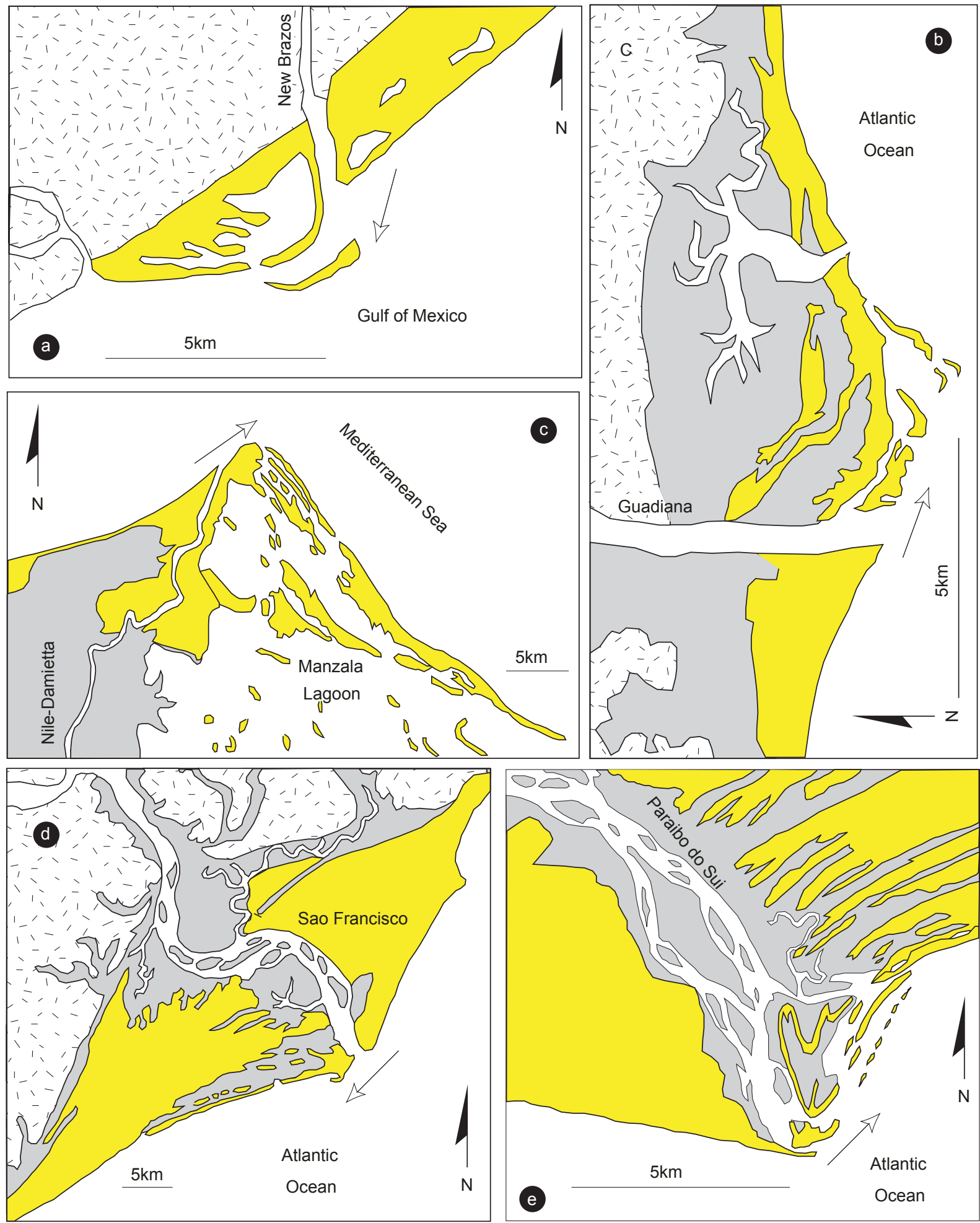

Fig. 3 Morphology and facies of other asymmetric deltas and/or deltaic lobes. (a) the New Brazos delta, Texas, USA. (b) the Guadiana delta, Spain/Portugal. (c) the Damietta lobe of the Nile delta, Egypt. (d) the Sāo Francisco delta and (e) Paraibo do Sul delta from the east Brazilian coast. Longshore drift direction is shown in each example by a white arrow at the river mouth. Each case is characterized by continuous sheet-like sands on the updrift and heterolithic muddy facies interfingering with linear sands on the downdrift. Sand bodies are colored in yellow; deltaic plain features other than sand bodies are colored in grey; areas that are not part of the modern deltaic complex are stippled. Data from Dominguez et al. (1987), Fanos et al. (1993), Dominguez (1996), Morales (1997), Rodriguez et al. (2000), and Bhattacharya and Giosan (2003).

\subsection{Other modern asymmetric deltas}

The Brazos River has the largest discharge into the Gulf of Mexico in Texas, USA. Its initial entrance into the gulf is located in the Freeport City. The course of the river was redirected in 1929 to alleviate city subsidence due to continuous deposition and loading of the old delta. This initiated a new delta, the New Brazos delta, $10 \mathrm{~km}$ westward. 
Under the control of waves and longshore drift in the gulf, the new delta shows asymmetry (Fig. 3a). The updrift (northeast) consists of typical sandy beach and shoreface deposits and the downdrift is muddier with lagoon muddy facies and linear sandy ridges. Rodriguez et al (2000) showed that sediments on the updrift side are mainly transported from the old Brazos delta by longshore currents and the sand ridges on the downdrift side are formed by reworking of the mouth-bar deposits. River floods and basinal wave processes play major roles in reshaping river mouth bars into the sand ridges (Hamilton, 1995; Rodriguez et al, 2000). During river floods, large amount of sediments are carried to the mouth of the Brazos River and are further transported basinward, resulting in narrow, shore-normal sedimentary bodies. During non-flood periods, sediments in these bodies are reworked and transported shoreward, forming subaerial shore-parallel sand ridges. The ridges grow and elongate continuously and their downdrift ends can attach to the delta in several years (Hamilton, 1995; Rodriguez et al, 2000). Closed, semi-closed lagoon, bay, and marsh environments are common behind the linear ridges. Muddy successions deposited in these environments typically interfinger with very fine-grained sands washed over the ridges during large storms.
The Guadiana, the Damietta lobe of the Nile, the Saō Francisco, the Paraibo do Sul, the Jequitinhona are all typical asymmetric deltas and/or delta lobes along the modern coasts (Figs. 3b-3e). The Guadiana delta (Fig. 3b), located at the bounder between Spain and Portugal, consists of sheet-like shoreface sands on the west side and mixed sand ridges and marsh deposits on the east side. Similarly, the Damietta lobe in the Nile delta also shows asymmetric facies and morphology. On the downdrift side, the lobe consists of a series of barrier islands and sandy spits encased in lagoon mudstones (Fig. 3c). These linear sand bodies, separating the Manzala lagoon from the open Mediterranean Sea, are composed mainly of very fine- to fine- grained sands and are formed by reworking of river mouth bars by wave processes (Sestini, 1989). The rate of longshore transport at the river mouth is extremely high, up to $4 \times 10^{5} \mathrm{~m}^{3} /$ year (Fanos et al., 1991; Fanos et al., 1993). The Saō Francisco delta consists of laterally continuous sandy shoreface deposits on the updrift side and mixed nearly shore-parallel barrier island, fluvial floodplain, and overbank fines on the downdrift side (Fig. 3d). Maturity analysis shows that sands on the downdrift have lower maturity than those on the updrift (Dominguez et al, 1987; Dominguez, 1996).

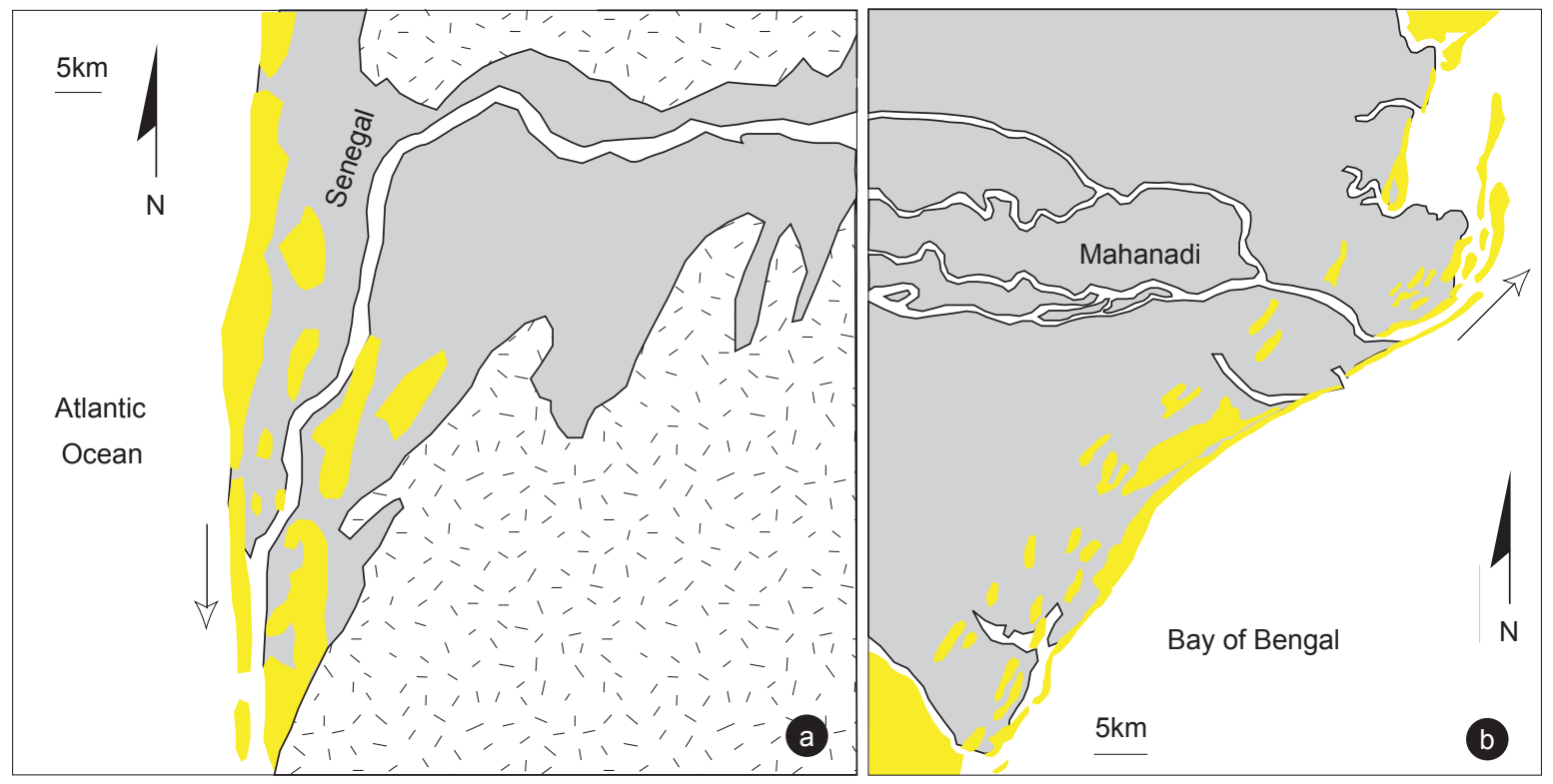

Fig. 4 Morphology and facies of deflected deltas. (a) Senegal delta, Senegal. (b) Mahanadi delta, India. In each case sediments from the feeding river melt onto the downdrift elongating barrier and river mouth moves gradually downdriftward, resulting in a shore-parallel river course. Sand bodies are colored in yellow; deltaic plain features other than sand bodies are colored in grey; areas that are not part of the modern deltaic complex are stippled.

\subsection{Deflected deltas}

With increasing longshore drift, the degree of asymmetry increases accordingly, resulting in deflected deltas. Typical modern deflected deltas include the Senegal delta in the west coast of Africa and the Mahanadi delta in the east coast of India (Figs. 4a, 4b). Compared with river discharge, longshore drift plays a more important role in controlling the facies and morphology in these deltas. In the Senegal delta, for instance, sediments carried to the river mouth are transported very quickly southward by longshore currents, merging into the shore-parallel barrier islands (Wright, 1985). Thus, during the growth of deflected deltas, river mouths migrate nearly shoreparallel, resulting in shore-parallel channels that are separated by elongated barrier islands from the open sea (Figs. 4a, 4b).

\section{Depositional characteristics and models}

Delta asymmetry occurs widely along modern coasts. It has also been observed in the ancient record, particularly in the deltaic-shallow marine successions deposited in the foreland basins of the Cretaceous Interior Seaway of 
North America (Hampson and Howell, 2005; Hansen and MacEachern, 2007; Li, 2009; Charvin et al., 2010; Li et al., 2010). Asymmetric deltas were identified in the Campanian Blackhawk and Castlegate formations of the Book Cliffs in eastern Utah (Hampson and Howell, 2005), the Campanian Basal Belly River Formation in Alberta, Canada (Hansen and MacEachern, 2007), and the Turonian Ferron Notom delta in southern Utah, USA (Li, 2009; Li et al., 2010). Based on observations in both modern and ancient examples, depositional characteristics and models for asymmetric deltas are elaborated in the following.

\subsection{Morphology and facies asymmetry and along-strike transition in facies}

Wave-influenced symmetric deltas (e.g. the Ebro delta in Spain; Tiber delta in Italy; the Godavari delta in India) are well developed in strongly wave-influenced setting where there is negligible long-shore drift and transport. These deltas have traditionally been depicted as having arcuate/ cuspate shapes with evenly distributed shoreface-type sand bodies on both sides of the feeding rivers (Galloway, 1975; Bhattacharya and Walker, 1992; Reading and Collinson, 1996). In classifying wave-influenced deltas, these classic models have, to a different extent, bias to symmetric deltas and asymmetric wave-influenced deltas are largely ignored, despite the fact that morphological and facies differences between opposite sides of river mouths in a number of strongly wave-influenced deltas have long been identified (e.g. Fig. 3 in Wright and Coleman, 1973; Fig. 24 in Coleman and Wright, 1975; Dominguez et al., 1987; Dominguez, 1996).

Unlike symmetric strongly wave-influenced deltas, asymmetric deltas show morphology and facies asymmetry between the updrift and the downdrift sides and are characterized by distinct transition in facies along depositional strike from strongly wave-influenced beach and shoreface facies on the updrift, to river-dominated facies at or near the main feeding river, and to mixed river- and wave-influenced facies on the downdrift (Figs. 2, 3).

Wave processes are dominant on the updrift side and the resultant deposits are typical continuous, homogeneous, coarsening-upward beach and shoreface successions. At or close to the river mouth, river processes are more typical. Under the control of hyperpycnal floods and high sedimentation rates, deposits are characterized by riverdominated, heterolithic, coarsening-upward prodelta to delta-front successions, with common occurrence of growth faults, soft-sediment deformation, and graded bedding. The downdrift deposits are commonly affected by mixed wave and river processes and, rather commonly, vegetation, and are characterized by muddy lagoon, bay-fill, and/or lake deposits with sandy linear bars, barriers, spits. Small bayhead deltas

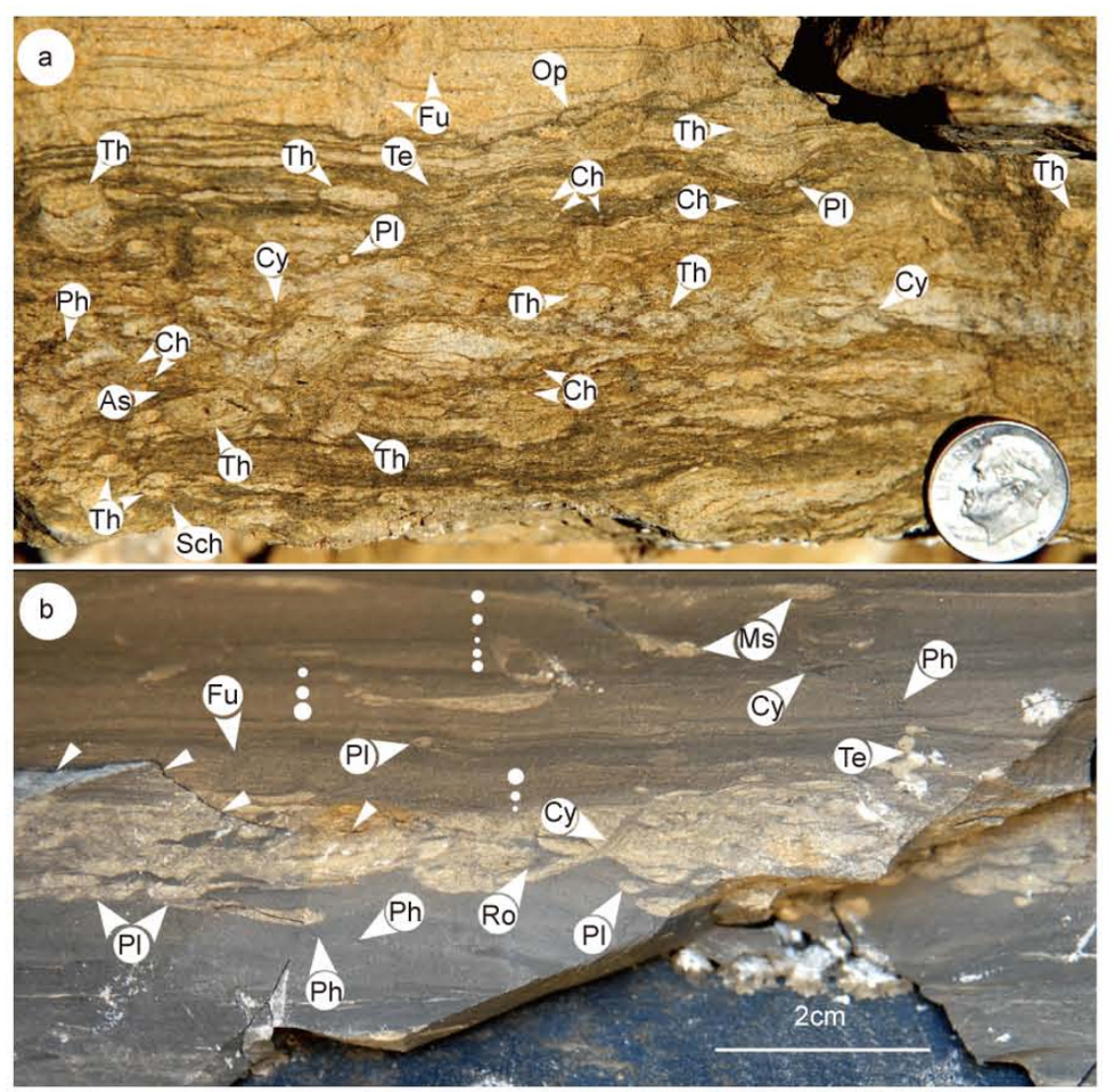

Fig. 5 Facies and burrowing fabric in (a) wave- and (b) river-dominated successions in one of the asymmetric lobes identified in the Turonian Ferron Notom delta in southern Utah, USA. (a) Highly burrowed lower shoreface muddy sandstone from the updrift side of the asymmetric lobe. Structures reflect archetypal suites and indicate more normal marine conditions. The occurrence of Asterosoma (As), Chondrites (Ch), Thalassinoides (Th), Teichichnus (Te), Planolites (Pl), Cylindrichnus (Cy), Schaubcylindrichnus freyi (Sch), and Phycosiphon (Ph), suggests a suite attributable to the Cruziana Ichnofacies. (b) High bioturbation spike in overall unburrowed prodelta mudstones from river-dominated successions close to the rive mouth of the lobe. The highly burrowed interval is erosively truncated by the largely unburrowed, normal- and/or inversely-graded mudstones (white circles), probably indicating the emplacement of hyperpycnal flows. Ichnogenera shows low diversity with Planolites (Pl), Teichichnus (Te), Phycosiphon (Ph), Cylindrichnus (Cy), and Rosselia (Ro). Fugichnia and equilibrichnia (Fu/Eq) and "mantle and swirl" structures (MS) are common. After Li et al (2010). 
may prograde into the semi-closed environments behind these linear bodies, resulting in river-dominated coarsening-upward successions. In contrast to the flat and even morphology on the updrift side, the downdrift is rougher with highs and lows controlled by different depositional elements.

\subsection{Ichnological response to along-strike changes in depositional processes}

With these along-strike changes in depositional processes and facies in asymmetric deltas, ichnology shows corresponding changes. The updrift side is strongly waveinfluenced, with low sedimentation rate. Persistent wave agitation can not only bring sufficient nutrients and oxygen to the water bottom but also contribute to maintaining a stable and consistent substrate (Gingras and MacEachern, 1998; MacEachern et al, 2005; Coates and MacEachern, 2007). These are all favorable for the survival, activities, and reproduction of trace makers. Burrowing intensity, accordingly, is high, with a bioturbation index (sensu Taylor and Goldring, 1993) of 3-6. Ichnogenera suites suggest healthy and robust Cruziana and Skolithos Ichnofacies (Fig. 5a).

At or near the river mouth, frequent river hyperpycnal flow conditions and high sedimentation rates are characteristic. Both hyperpycnal flows and high sedimentation rates can, in turn, increase water turbidity and result in an inconsistent substrate by triggering delta-front instability and turbidity currents (Mulder et al, 2003; Plink-Björklund and Steel, 2004; Bhattacharya and MacEachern, 2009). All these are detrimental for the trace makers. In response, burrowing intensity is overall low (BI 0-2), but with common occurrence of high bioturbation spikes with BI of 4-6. Ichnogenera are characterized by horizontal, morphologically simple, and facies-crossing structures of inferred deposit feeders and carnivores (Gingras and MacEachern, 1998; MacEachern et al., 2005; Coates and MacEachern, 2007; Li, 2009; Li et al, 2010). Typical ichnogenera include Planolites, Palaeophycus, Phycosiphon, Teichichnus, Thalassinoides, and delimitative Rosselia and Cylindrichnus (Fig. 5b, Table 1). High sedimentation rates and soupy substrate also lead to the wide occurrence of "mantle and swirl" structures, fugichnia, and equilibrichnia in the prodelta to delta-front successions (Fig. 5b, Table 1).

On the downdrift side, river processes are common. Away from the river mouth, however, wave processes and wave reworking are also common. Bioturbation intensity is, thus, variable. River-dominated bayhead deltas sheltered behind barriers and/or bars show burrowing intensity and fabric similar to those in the river-dominated successions described above. Barriers and bars, due to persistent wave reworking, are highly burrowed, bearing robust and healthy ichnogenera similar to those in the typical shoreface deposits on the updrift side (Table 1). Closed, semi-closed lagoons and bays commonly have poor circulation and vertical oxygen and salinity stratification. Only trace makers having specialized feeding and living behaviors can tolerate such stressed environments. The resultant ichnogenera accordingly have low diversity and, commonly, high abundance. Common ichnogenera in these environments include Gyrolithes, Planolites, Palaeophycus, Teichichnus, and Thalassinoides.

\subsection{Depositional models}

Delta asymmetry commonly forms in wave-influenced settings where there are strong net longshore currents. The

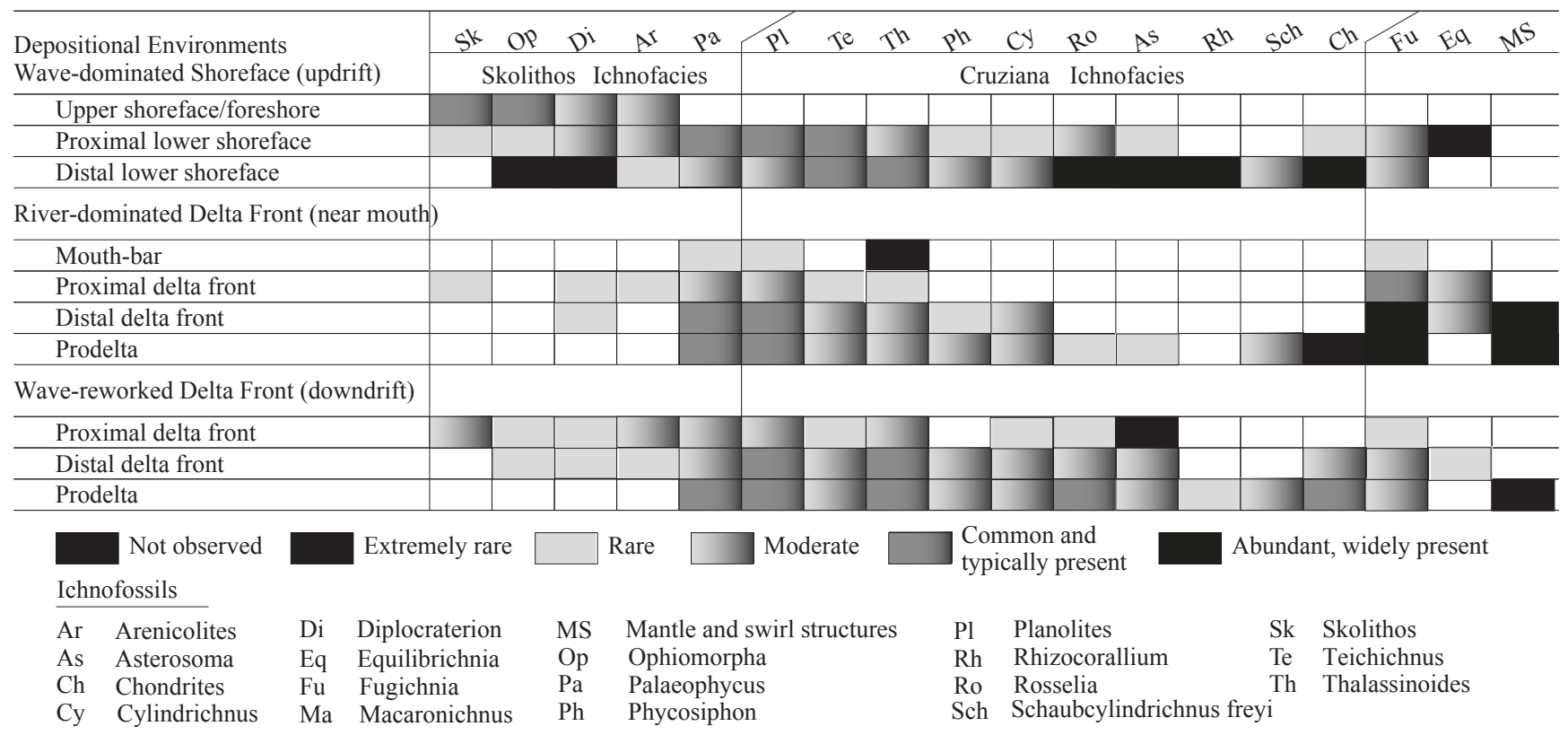

Table 1 Summary of biogenetic structures in the same asymmetric lobe identified in the Turonian Ferron Notom delta in southern Utah as shown in Fig. 5. Ichnogenera in the wave-dominated shoreface on the updrift consist of diverse and robust biogenetic structures typical of either the Cruziana or the Skolithos Ichnofacies. In contrast, trace fossils in the river-dominated delta front are of low diversity and dominated by morphologically simple, facies-crossing elements, consistent with stressed expressions of the Skolithos or the Cruziana Ichnofacies. The common occurrence of fugichnia, equilibrichnia, and "mantle and swirl" structures are consistent with the presence of marked physico-chemical stresses at or near the river mouth. Biogenic structures in the wave-reworked delta-front facies on the downdrift side show higher abundances and diversity than those in the river-dominated successions. In some cases, suites show greater affinity with those of the wave-dominated shoreface facies. After Li et al (2010). 
formation of strong longshore drift requires oblique waves approach the shoreline constantly from one direction or oblique waves approaching the shoreline from one direction that are considerable stronger than those from the other directions. Along stepper shelves, energy loses during wave propagation due to friction between waves and water bottom is smaller. Thus, net longshore currents formed when deepwater waves pass a stepper shelf and approach the shoreline obliquely at an angle is stronger than these waves pass a gentler shelf and approach the shoreline at the same angle. River discharge also has a great impact on the development of asymmetric deltas. High discharge rates not only provides sufficient sediments for the growth of the barriers, bars, and/or sandy ridges on the downdrift but also form a groyne effect, which effectively prevents sediments carried by longshore currents from bypassing the river mouth. This contributes for the growth of the shoreface facies on the

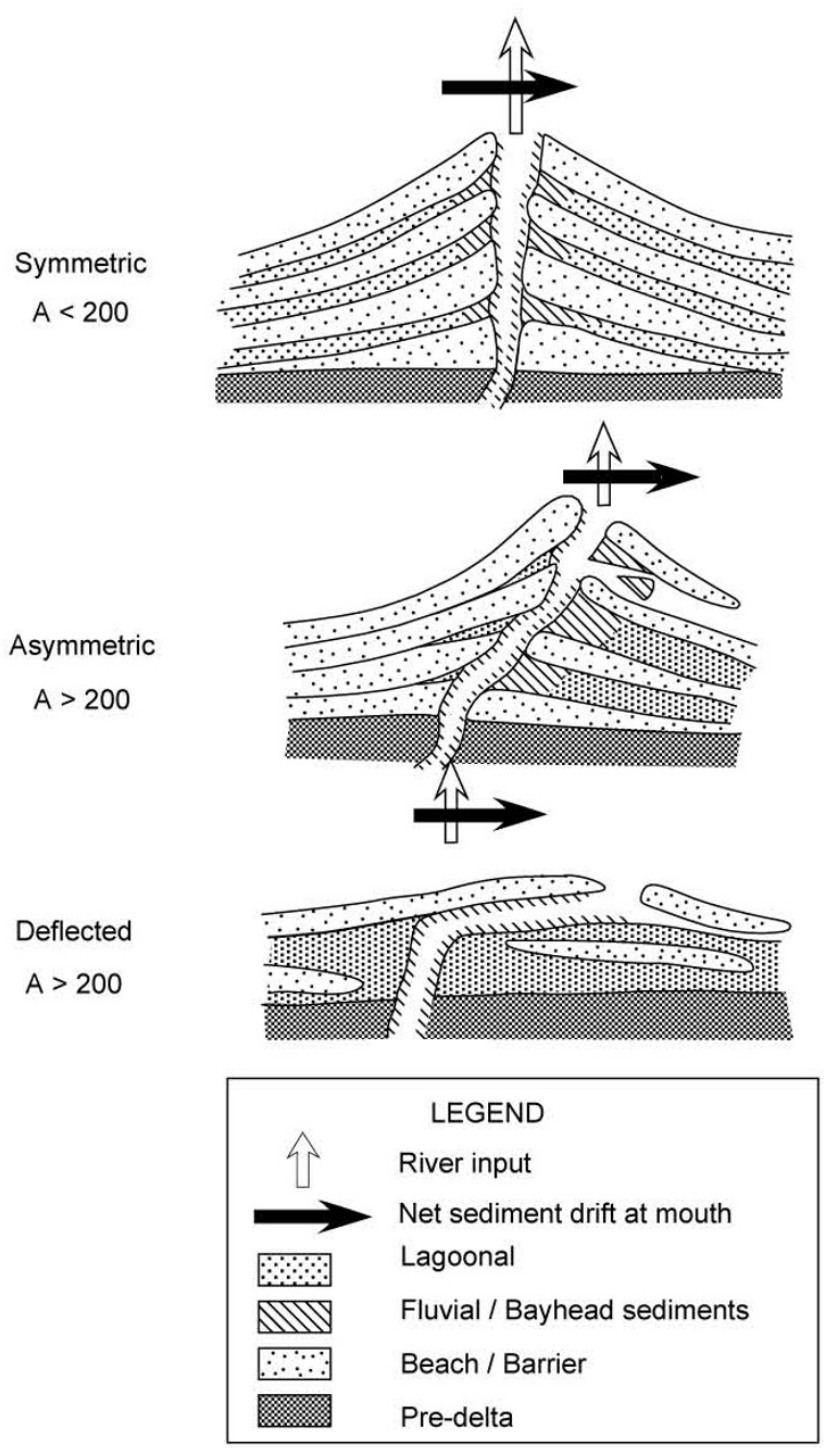

Fig. 6 Depositional model of wave-influenced deltas. The asymmetry index (A), defined as the ratio between the rate of longshore transport at the river mouth and river water discharge, is used to evaluate the morphologies and facies asymmetry of these deltas. The index in wave-influenced symmetric delta is less than 200. Those in asymmetric and deflected deltas are larger than 200, and morphology and facies asymmetry increase with increasing index values. updrift side.

Recognizing the relative importance of longshore transport at the river mouth $\left(\mathrm{m}^{3} /\right.$ year) with respect to river water discharge $\left(10^{6} \mathrm{~m}^{3} / \mathrm{month}\right)$ in controlling the facies and morphology of asymmetry deltas, Bhattacharya and Giosan (2003) defined the ratio between these two as the asymmetric index (A) and used it in evaluating the degree of asymmetry (Fig. 6). In wave-influenced symmetric deltas, the index is typically less than 200; in asymmetric and deflected deltas, the index is larger than 200 and overall the larger the index, the higher the degree of asymmetry.

The formation of delta asymmetry also requires a second source to provide sufficient sediments for the growth of the updrift side. This can be another active delta and/or river mouth, an abandoned delta, earlier lowstand shelf deposits, etc.

Wave processes play an important role in the formation of asymmetric deltas in that wave reworking mouth-bar and subaqueous deposits leads to the development of the linear, shore-parallel sandy barriers, bars, and/or ridges on the downdrift side. Bars can form in several months or years (e.g. bars on the downdrift of the New Brazos delta, Fig. 7) or up to several hundred years or even longer (e.g. bars on the downdrift of the Sf. Gheorghe lobe of the Danube delta). Closed or semi-closed environments such as lagoons, bays, and lakes can develop behind the linear sedimentary bodies. These environments, with low energy, are typically not directly affected by waves. Tidal processes, however, can affect the inflow and outflow of sediments and small channels bifurcated from the main feeding rivers can bring sediments into these environments, resulting in small river-dominated bayhead deltas (b1 and b2 in Fig. 2).

\section{Facies controlled by shoreline trajectory and reworking after deposition}

Facies types and characteristics of asymmetric deltas are governed by riverine, longshore drift, and basinal wave processes. Shoreline trajectories during delta progradation and reworking after deposition, however, are also important controlling factors (Fig. 8).

The shoreline trajectory concepts tie movements of shoreline and changes in accommodation to depositional processes in a sequence stratigraphic framework (HellandHansen and Martinsen, 1996). During forced regression, for instance, the shoreline moves basinward and downward stepwise, resulting in a negative trajectory (Fig. 8, scenario a). Fluvial-deltaic systems formed during forced regression, thus, typically lack the full development of fluvial plain, coastal plain, and the deltaic top sets because there is zero or even negative accommodation behind the shoreline during each stage of progradation (Fig. 8, A). In contrast, during late lowstand and highstand, shoreline moves basinward and upward, leading to a positive trajectory (Fig. 8, scenario b). Such facies are better developed in that there is sufficient accommodation immediately behind the prograding shoreline (Fig. 8, B).

Reworking after deposition, especially transgressive shoreface erosion, also largely controls the type of facies 

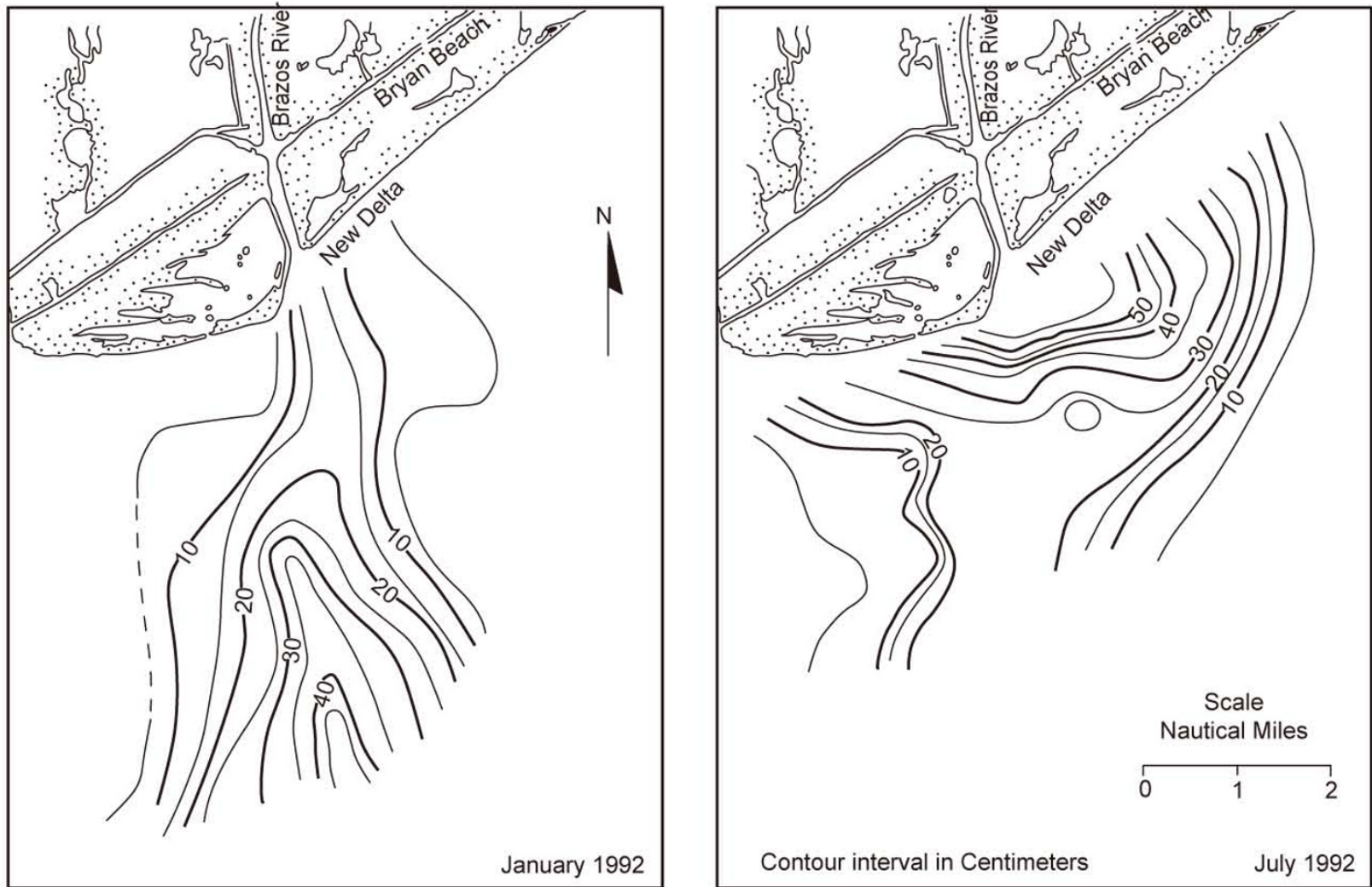

Fig. 7 Isopach maps showing reworking of the mouth-bar and subaqueous deposits by wave process in the New Brazos delta. The shore-normal, elongated offshore sediments deposited after a river flood in January 1992 was rapidly reworked shoreward in several months (the July map). Eventually these sediments became emergent to form an offshore bar on the downdrift side of the delta. Data from Hamilton (1995).

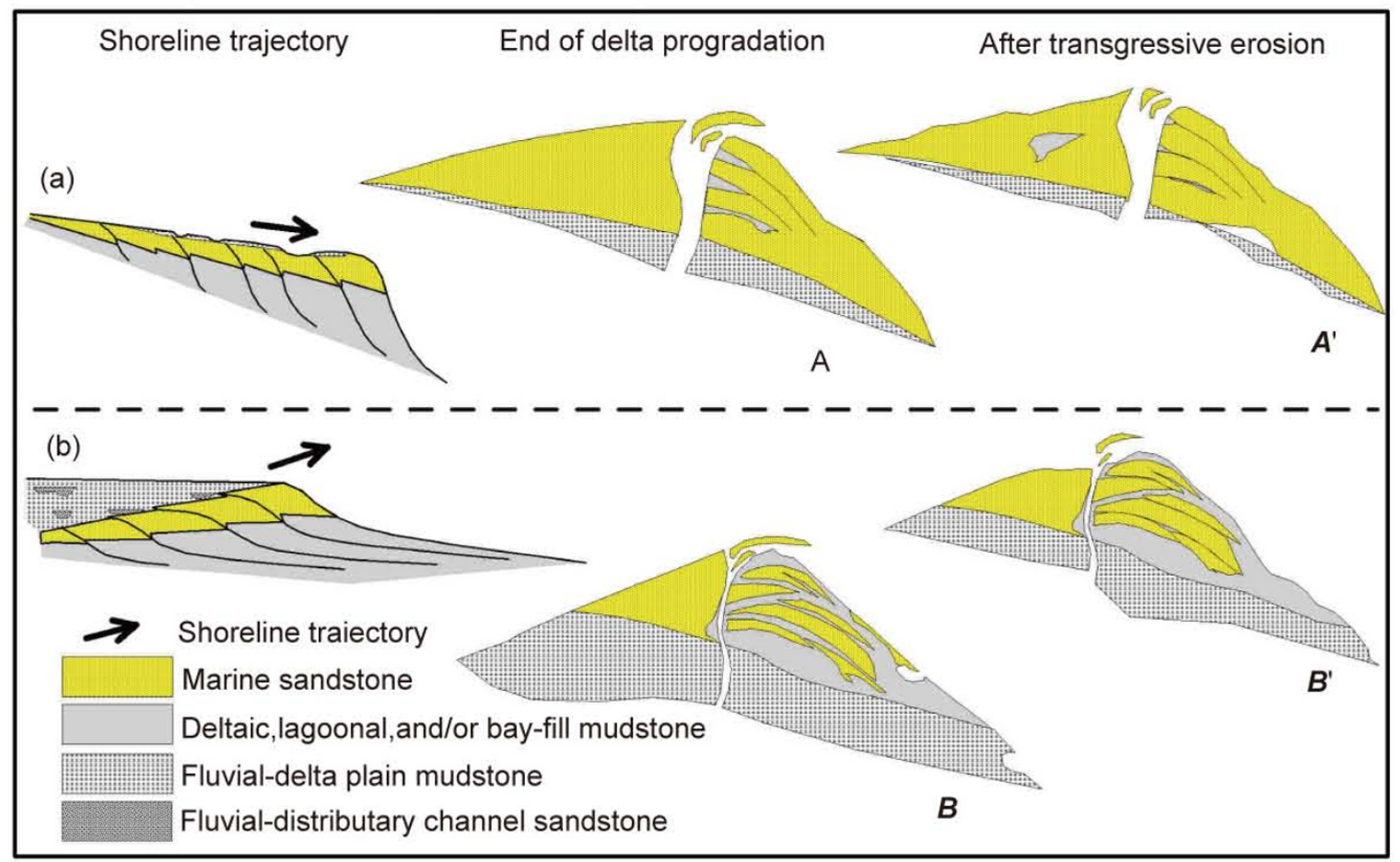

Fig. 8 Schematic diagrams showing facies of asymmetric deltas as a function of shoreline trajectory and depositional history. Scenario (a): Deltaic shoreline progrades under a negative trajectory. The resulting delta consists of low proportions of muddy paralic, lagoon, and bay-fill deposits due to minimized or even negative accommodation behind the shoreline (A). Such deltas are especially susceptible to subsequent erosion during transgression, as have been previously documented (Posamentier and Allen, 2000; Bhattacharya and Willis, 2001; Bhattacharya, 2006). In extreme cases, erosion may be so deep that the underlying marine mudstones are exposed $\left(\mathrm{A}^{\prime}\right)$. Scenario (b): Shoreline progrades under a positive trajectory. The resultant delta is expected to have significant amounts of muddy lagoon and bay deposits on the downdrift side and widespread fluvial-delta plain facies further landward, because at each stage of progradation there is sufficient accommodation for such deposits to accumulate (B). Due to transgressive erosion, however, the muddy lagoon and bay-fill deposits can be largely eroded, leaving sandier facies and a transgressive lag behind. Notice that, in both cases the isolated barriers are "apparently" attached after the muddy facies have been effectively removed. After Li et al (2010). 
preserved in the ancient record (Fig. 8, $\mathrm{A}^{\prime}, \mathrm{B}^{\prime}$ ). Depending on the shape of the shoreface and shoreface-shelf physiography, shoreface erosion can be up to tens of meters. In the Cretaceous Interior Seaway of North America, average erosional thickness is 10-20m (Bergman and Walker, 1988; Walker, 1995; Bhattacharya and Willis, 2001).

The delta asymmetry models described above predict that there are sandy beach and shoreface deposits on the updrift side and muddier and more heterolithic barrier, bar, lagoon, bay-fill facies on the down drift. Recent studies, however, show that facies in the ancient asymmetric deltas don't always fit this model. The asymmetric lobe identified in the Turonian Ferron Notom delta in southern Utah, for example, is overall sandy and lacks fluvial plain and coastal plain deposits ( $\mathrm{Li}$, 2009; Li et al, 2010). Muddy lagoon, bay-fill, and/or lake facies are also largely absent on the downdrift side. Regional sequence stratigraphic analysis ( $\mathrm{Li}$ et al, 2008; Li, 2009; Li et al, 2010; Li et al, 2010) demonstrates that the lobe was formed during a forced regression and the overall lack of such facies is partially due to zero or negative accommodation behind the shoreline during delta progradation. The thick lag overlying the asymmetric lobe indicates that such facies, if developed, must have also undergone shoreface erosion during the ensuing transgression.

\section{Study significances}

\subsection{Implications for the definition and classification of deltas}

A delta is traditionally defined as "a protuberance sourced mainly by a river that enters a standing body of water and supplies sediments at a rate faster than the reworking of basinal processes" (Elliott, 1986; Alexander, 1989). This definition implies that river channels should locate behind the delta front and run in shore-normal directions. Studies of asymmetric deltas, however, show that 1) sediments on the updrift of these deltas are mainly from secondary sources, which may supply a larger amount of sediments than the feeding rivers (for example, the Saō Francisco delta and the Senegal delta), and 2) the river mouth in deflected deltas moves gradually downdrift, resulting in shore-parallel river channels. The traditional definition of deltas, thus, can not cover these characteristics of asymmetric deltas and should be relaxed.

Analysis of asymmetric deltas also exposed the weakness in the process-based classification of deltas (Wright and Coleman, 1973; Coleman and Wright, 1975; Galloway, 1975) (Fig. 1). One of the main problems in classifying deltas is to force-fit a lobe or even a complex delta as a single point in the tripartite classification diagram. Asymmetric deltas show rapid along-strike transition in facies from wave-dominated beach and shoreface on the updrift, to river-dominated prodelta and delta front at or near the river mouth, and to mixed wave- and river--influenced deposits on the downdrift (Figs. 2, 3, 4). Simply classifying these deltas as river- or wave-dominated will underestimate their internal facies complexity. During the progradation of a deltaic system, several lobes can be active at a particular time. A typical example is the modern Danube delta. To the south is the strongly wave-influenced asymmetric Sf. Gheorghe lobe and to the north is the river-dominated Chilia lobe (Fig. 2). These two have very different facies types and, thus, classifying the delta as either river-dominated or wave-dominated will underestimate its internal facies complexity.

\subsection{Implications for the identification of depositional systems}

Delta asymmetry models challenge the traditional view of depositional elements and systems. Barriers, bars, and lagoons are commonly deemed as typical elements of transgressive systems (Galloway, 1996). The current study, however, shows that they can also be components of large asymmetric deltas (Figs. 2, 3, 4). Bays and bayhead deltas are regarded as diagnostic features for the development of valleys (Zaitlin et al., 1994; Boyd et al., 2006); these, however, are also elements of asymmetric deltas. Similarly, typical beachshoreface-strandplain deposits occur not only in prograding wave-dominated shorelines, but also in the updrift side of large asymmetric deltas. In paleogeographic reconstruction

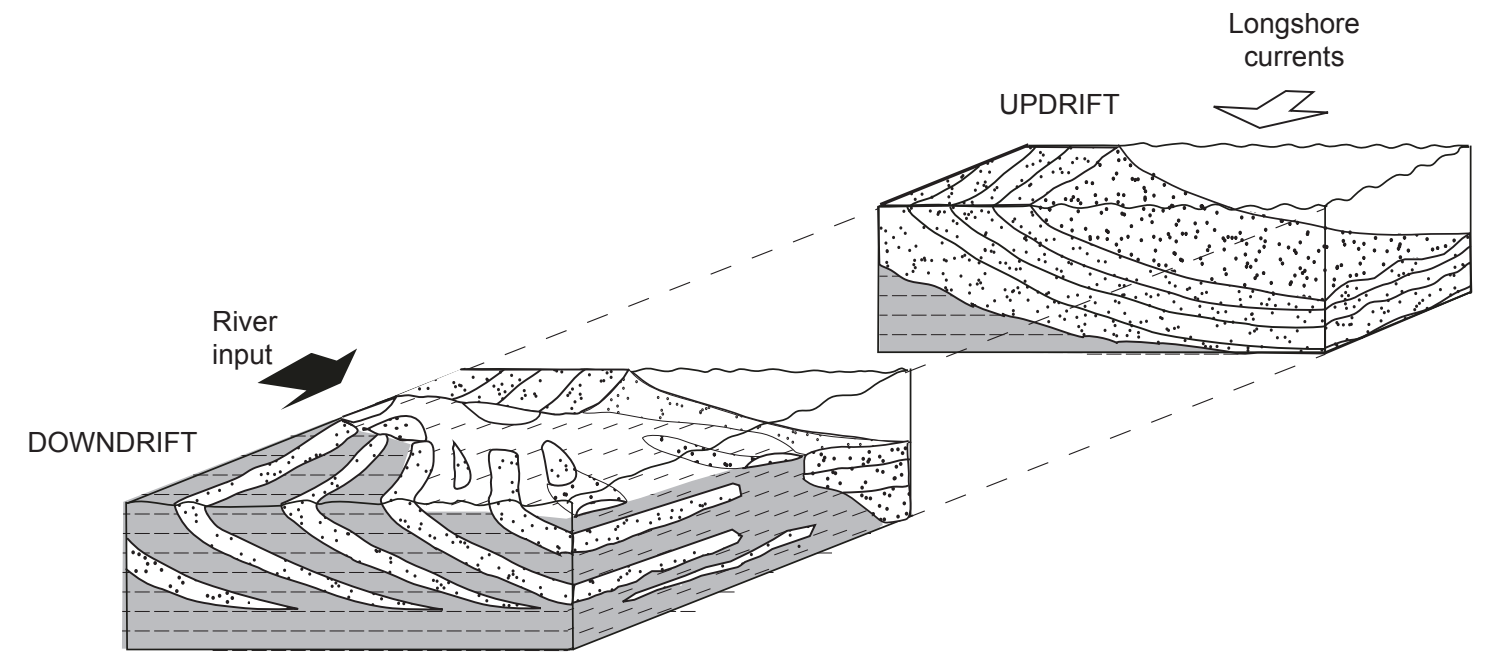

Fig. 9 Block diagram illustrating the inferred three-dimensional facies architecture of asymmetric deltas. Significant prodelta, bay-fill, and lagoon mudstones are on the downdrift side where sandy barriers, bars, and spit are encased in these mudstones. The updrift side of the delta comprises sandy beach and shoreface successions. The associated hydrocarbon reservoirs between the updrift and the downdrift sides are, thus, very different in terms of laterally continuity and heterogeneity. 
and identifying depositional elements and systems, one, thus, needs to be open-minded and consider the problem in different scales to avoid misidentification.

\subsection{Significance for hydrocarbon exploration}

The sheet-like beach-shoreface sands on the updrift of asymmetric deltas are more mature, laterally continuous, and homogeneous; in contrast, the linear barrier and bar sands on the downdrift show lower maturity and less lateral continuity and are commonly encased in muddy facies (Fig. 9). The resultant hydrocarbon reservoirs have very different properties. Those on the downdrift side show higher heterogeneity and should be treated separately during exploration and production.

Strong longshore drift is one of the main factors that control the facies and reservoir architecture in asymmetric deltas. It occurs widely along modern shallow shelves (Dominguez et al., 1987; Hamilton, 1995; Dominguez, 1996; Rodriguez et al, 2000; Bhattacharya and Giosan, 2003) (Figs. $2,3,4)$ and has also been identified in many paleoshorelines, particularly those in the Cretaceous Seaway of North America (Hampson and Howell, 2005; Hansen and MacEachern, 2007; Li, 2009; Li et al, 2010). This suggests that net longshore drift is most probably commonly developed in the ancient record. Deltaic-shallow marines successions deposited on the shallow shelves of the Cenozoic basins are one of the most important exploration targets in China. The Oligocene-Miocene Zhujiang-Zhuhai formations in the Pearl River Mouth Basin and the Miocene Sanya-Huangliu formations in the Qiongdongnan Basin, for example, are all major exploration zones. Studies investigating the occurrence and intensity of waves and longshore drifts and how they control and reshape the facies and internal architecture of these deltaic-shallow marine systems, however, are largely absent and should be addressed in future hydrocarbon explorations efforts.

\section{Conclusions}

1) Delta asymmetry typically forms in wave-influenced settings where there is strong net longshore transport. Asymmetric deltas are characterized by morphology and facies asymmetry between the updrift and the downdrift sides.

2) Delta asymmetry models suggest that longshore currents play a critical role in the growth of asymmetric deltas by transporting sediments alongshore to the updrift side. By blocking sediments carried by longshore currents bypassing the river mouth, river input also plays an important role. An asymmetry index (A), defined as the ratio between rate of longshore transport at the river mouth and river water discharge, is used to evaluate the degree of asymmetry. The larger the index, the higher the degree of asymmetry; asymmetric deltas typically have an index of 200 or larger. A second sediment source and basinal wave processes are also important in providing sufficient sediments for the growth of the updrift and reworking mouth bars into linear sand bodies.

3) Along depositional strike there is commonly rapid facies transition in asymmetric deltas. The updrift is sandier and commonly consists of strongly wave-influenced beach and shoreface facies. Deposits show higher bioturbation
(BI 3-6) and ichnogenera are characterized by a robust and healthy suite attributable to the Cruziana and Skolithos ichnofacies. At or close to the main feeding river, heterolithic river-dominated facies are common. Deposits show overall low burrowing (BI 0-2), but with common occurrence of high bioturbation spikes. Ichnogenera are commonly horizontal, morphologically simple, and facies crossing. The downdrift side is muddier, more heterolithic and consists of mixed wave- and river-influenced successions with variable bioturbation intensity.

4) Depending on shoreline history and reworking after deposition, particularly transgressive erosion, facies of asymmetric deltas preserved in the ancient may be different from those predicted by the asymmetry models. Analysis in the ancient record needs to involve shoreline trajectory and regional sequence stratigraphic control.

5) Delta asymmetry models challenge the traditional definition and process-based classification of deltas. A better understanding of the characteristics and formation mechanism of asymmetry deltas also contribute to robustly identifying different depositional systems and guide future hydrocarbon exploration in deltaic-shallow marine deposits.

\section{Acknowledgements}

We thank William R. Dupré and James R. Garrison, "Jr." for reviewing a draft version of the manuscript and helping to clarify some of the ideas in the paper. This study is also supported by the National Basic Research Program of China (No. 2009CB219407) and the National Natural Science Foundation of China (No. 40972077). Mark Barton, Bryan Bracken, Ed Westergaard, and Howard White provided many valuable insights in the course of our field work, and we thank them for their comments and suggestions.

\section{References}

Alexander J. Deltas or coastal plain? with an example of the controversy from the Middle Jurassic of Yorkshire. In: Whateley M K G, Pickering K T, eds. Deltas: Sites and Traps for Fossil Fuels. London: Geological Society of London, Special Publication 41. 1989. 11-19

Bergman K M and Walker R G. Formation of Cardium E5 erosion surface, and associated deposition of conglomerate: Carrot Creek field, Cretaceous western interior seaway, Alberta. In: James D P, Leckie D A, eds. Sequences, Stratigraphy, Sedimentology, Surface and Subsurface, Canadian Society Petroleum Geologists, Memoir 15. 1988. 15-24

Bhattacharya J P. Deltas. In: Walker R G, Posamentier H, eds. Facies Models Revisited. Tulsa: SEPM, Special Publication 84. 2006. 237 292

Bhattacharya J P and Giosan L. Wave-influenced deltas: geomorphological implications for facies reconstruction. Sedimentology. 2003. 50: 187-210

Bhattacharya J P and MacEachern J A. Hyperpycnal rivers and prodeltaic shelves in the Cretaceous Seaway of North America. Journal of Sedimentary Research. 2009. 79: 184-209

Bhattacharya J P and Walker R G. Deltas. In: Walker R G, James N P, eds. Facies Models: Response to Sea-Level Change. St Johns: Geological Association of Canada. 1992. 157-177

Bhattacharya J P and Willis B J. Lowstand deltas in the Frontier Formation, Powder River Basin, Wyoming: implications for sequence stratigraphic models, USA. AAPG Bulletin. 2001. 85: 261294 
Boyd R, Dalrymple R W and Zaitlin B A. Estuarine and incised valley facies models. In: Walker R G, Posamentier H, eds. Facies Models Revisited. Tulsa: SEPM, Special Publication 84. 2006. 171-235

Charvin K, Hampson G J, Gallagher K L and Labourdette R. Intraparasequence architecture of an interpreted asymmetrical wavedominated delta. Sedimentology. 2010. 57: 760-785

Coates L and MacEachern J A. The ichnological signatures of riverand wave-dominated delta complexes: differentiating deltaic from non-deltaic shallow marine successions, Lower Cretaceous Viking Formation and Upper Cretaceous Dunvegan Formation, west-central Alberta. In: MacEachern J A, Bann K L, Gingras M K, et al, eds. Applied Ichnology. Tulsa: SEPM, Short Course Notes 52. 2007. 227-254

Coleman J M and Wright L D. Modern river deltas: variability of processes and sand bodies. In: Broussard M L, ed. Deltas, Models for Exploration. Houston: Houston Geological Society. 1975. 99-149

Dominguez J M L. The Saō Francisco strandplain: a paradigm for wavedominated deltas? In: Baptist M De, Jacobs P, eds. Geology of Siliciclastic Shelf Seas. London: Geological Society of London, Special Publication 117. 1996. 217-231

Dominguez J M L, Martin L and Bittencourt A C S P. Sea-level history and Quaternary evolution of river mouth associated beach-ridge plains along the east-southeast Brazilian coast: a summary. In: Nummedal D, Pilkey O H, Howard J D, eds. SeaLevel Fluctuations and Coastal Evolution. Tulsa: SEPM, Special Publication 41. 1987. 115-127

Elliott T. Clastic shorelines. In: Reading H G, ed. Sedimentary Environments and Facies. 3rd ed. Oxford: Blackwell Science, 1986. $1-688$

Fanos A M, Frihy O E, Khafagy A A, et al. Processes of shoreline changes along the Nile delta coast of Egypt. In: Kraus N C, Gingerich K J, Kriebel D L, eds. Coastal Sediments 91. New York: American Society Civil Engineers. 1991. 1547-1557

Fanos A M, Khafagy A A, Komar P D. Erosion of the Damietta promontory, the Nile Delta. In: Edge W L, ed. Coastal Engineering 92. New York: American Society Civil Engineers. 1993. 3246-3259

Galloway W E. Process framework for describing the morphologic and stratigraphic evolution of deltaic depositional systems. In: Broussard M L, ed. Deltas, Models for Exploration. Houston: Houston Geological Society. 1975. 87-98

Galloway W E and Hobday D K. Terrigenous Clastic Depositional Systems--Applications to Fossil Fuel and Groundwater Resources. Berlin: Springer. 1996. 1-508

Gingras M K, MacEachern J A and Pemberton S G. A comparative analysis of the ichnology of wave- and river-dominated allomembers of the Upper Cretaceous Dunvegan Formation. Canadian Association of Petroleum Geologists, Bulletin. 1998. 46: 51-73

Giosan L. Long term sediment dynamics on Danube delta coast. In: Dronkers J, Scheffers M, eds. Physics of Estuaries and Coastal Seas. Balkema: Rotterdam. 1998. 365-376

Hamilton M D. Detailed facies analysis of the Brazos wave-dominated delta, Freeport, Texas. MSc Thesis. Rice University. 1995

Hampson G J and Howell J A. Sedimentologic and geomorphic characteristics of ancient wave-dominated deltaic shorelines: Upper Cretaceous Blackhawk Formation, Book Cliffs, Utah, USA. In: Giosan L, Bhattacharya J P, eds. River Deltas: Concepts, Models, and Examples. Tulsa: SEPM, Special Publication 83. 2005. 133-154

Hansen C D and MacEachern J A. Application of the asymmetric delta model to along-strike facies variation in a mixed wave- and river-influenced delta lobe, Upper Cretaceous Basal Belly River Formation, Central Alberta. In: MacEachern J A, Bann K L, Gingras M K, Pemberton S G. Applied Ichnology. Tulsa: SEPM, Short Course Notes 52. 2007. 256-269

Helland-Hansen W and Martinsen O J. Shoreline trajectories and sequences: description of variable depositional-dip scenarios. Journal of Sedimentary Research. 1996. B66: 670-688

Komar P D. Computer models of delta growth due to sediment input from rivers and longshore transport. Geological Society of America, Bulletin. 1973. 84: 2217-2226

Li W. Valleys, facies, and sequence stratigraphy of the Ferron Notom delta, Capital Reef, Utah. Ph.D dissertation. University of Houston. 2009

Li W, Bhattacharya J P and Campbell C. Temporal evolution of fluvial style within a compound incised valley, Ferron "Notom Delta", Henry Mountains region, Utah (USA). Journal of Sedimentary Research. 2010. 80: 529-549.

Li W, Bhattacharya J P, Zhu Y, et al. Evaluating delta asymmetry using 3D facies architecture and ichnological analysis, Ferron "Notom Delta”, Capital Reef, UTAH, USA. Sedimentology. 2010. 58: 478507.

Li W, Campbell C and Bhattacharya P J. Incised valley systems and sequence stratigraphy of the Ferron Sandstone, "Notom Delta", Henry Mountains region, Utah. Geological Society of America, Abstracts with Programs 40. 2008. 482-483

MacEachern J A, Bann K L, Bhattacharya J P, et al. Ichnology of deltas. In: Giosan L, Bhattacharya J P, eds. River Deltas: Concepts, Models, and Examples. Tulsa: SEPM, Special Publication 83. 2005. 49-85

Morales J A. Evolution and facies architecture of the mesotidal Guadiana River delta (SW Spain-Portugal). Marine Geology. 1997.138: 127148

Mulder T, Syvitski J P M, Migeon S, et al. Marine hyperpycnal flows: initiation, behavior and related deposits. A review. Marine and Petroleum Geology. 2003. 20: 861-882

Panin N. On the geomorphologic and geologic evolution of the River Danube-Black Sea interaction zone. Geo-Eco-Marina. 1997. 2: 2530

Plink-Björklund P and Steel R J. Initiation of turbidity currents: outcrop evidence for Eocene hyperpycnal flow turbidites. Sedimentary Geology. 2004. 165: 29-52

Posamentier H W and Allen G P. Siliciclastic Sequence Stratigraphy: Concepts and Applications. Tulsa: SEPM. 2000 1-204

Reading H G and Collinson J D. Clastic coasts. In: Reading H G, ed. Sedimentary Environments and Facies. 3rd ed. Oxford: Blackwell Science. 1996. 154-231

Rodriguez A B, Hamilton M D and Anderson J B. Facies and evolution of the modern Brazos Delta, Texas: wave versus flood influence. Journal of Sedimentary Research. 2000. 70: 283-295

Sestini G. Nile delta: a review of depositional environments and geological history. In: Whateley M K G, Pickering K T, eds. Deltas: Sites and Traps for Fossil Fuel. London: Geological Society of London, Special Publication 41. 1989. 99-127

Taylor A M and Goldring R. Description and analysis of bioturbation and ichnofabric. Journal of Geological Society of London. 1993. 150:141-148

Walker R G. Sedimentary and tectonic origin of a transgressive surface of erosion: Viking Formation, Alberta, Canada. Journal Sedimentary Research. 1995. B65: 209-221

Wright L D. River deltas. In: Davis A R, ed. Coastal Sedimentary Environments. New York: Springer-Verlag. 1985. 1-76

Wright L D and Coleman J M. Variations in morphology of major river deltas as functions of ocean wave and river discharge regimes. AAPG Bulletin. 1973. 57: 370-398

Zaitlin B A, Dalrymple R W and Boyd R. The stratigraphic organization of incised-valley systems associated with relative sea level change. In: Dalrymple R W, Boyd R, Zaitlin B A, eds. Incised-Valley Systems: Origin and Sedimentary Sequences. Tulsa: SEPM, Special Publication 51. 1994. 45-60

(Edited by Yang Lei) 